\title{
CHAROPHYTES OF THE LUBELSZCZYZNA REGION (EASTERN POLAND)
}

\author{
JACEK Urbaniak ${ }^{1}$, Piotr SugieR ${ }^{2}$, MACIEJ GĄBKA ${ }^{3}$ \\ ${ }^{1}$ Department of Botany and Plant Ecology \\ Wrocław University of Environmental and Life Sciences \\ pl. Grunwaldzki 24a, 50-363 Wrocław, Poland \\ e-mail: jacek.urbaniak@up.wroc.pl \\ 2 Department of Ecology, Maria Curie-Skłodowska University \\ Akademicka 19, 20-033 Lublin, Poland \\ ${ }^{3}$ Department of Hydrobiology, Adam Mickiewicz University \\ Umultowska 89, 61-614 Poznań, Poland
}

(Received: April 29, 2010. Accepted: October 15, 2010)

\begin{abstract}
The distribution and ecology of charophytes in Lubelszczyzna (Eastern Poland) is described based on herbaria collections, literature data, and the author's own investigations. Maps showing the distribution of all 22 charophyte species identified so far are presented, as well as the details of habitats ecology. Some data on species frequency, conservation, and threats are added.
\end{abstract}

KEY WORDS: Chara, Nitella, Lychnothamnus, Nitellopsis, charophyta, distribution, ecology, Poland.

\section{INTRODUCTION}

Charophytes (Characeae, Charophyta) are a component of the submerged aquatic vegetation in different but mostly stagnant or slow running waters. They occur in both fresh and brackish temporary and permanent water ranging from tiny ponds to large lakes. Charophytes are an old taxonomic group and are placed as basal to green plants or as their ancestors (Meiers et al. 1997; Karol et al. 2001; Urbaniak 2010). Charophytes are a group of macrophytes that is being affected by increasingly high human pressure on lakes. This leads to growing lake trophy and reductions in light availability. The close relationship between changes in water transparency and the occurrence of charophytes in lakes is commonly known: the light availability can be regarded as a major environmental factor determining the zonation of charophytes in deep lakes (Spence 1982; Coops 2002). Approximately 400 species of Characeae occur worldwide and to date about 33 (34) charophyte species have been recorded in Poland (Gąbka and Pełechaty 2006; Siemińska et al. 2006; Urbaniak 2007).

The flora and abundance of charophytes in Lubelszczyzna have been previously investigated by several authors. The first work to include the charophyte species was written by Fijałkowski (1959), who reported a total of nine species and gave their occurrence in lakes: Chara aspera, C. contraria, C. delicatula, C. globularis, $C$. intermedia, $C$. tomentosa, Nitella flexilis, N. mucronata, and Nitellopsis obtusa. The same species, except for $C$. delicatula, are also reported by Karczmarz (1963), who added C crassicaulis, C. hispida, C. rudis, and N. syncarpa as new species found in Lubelszczyzna. In another work written by Karczmarz (1965), two new species in the region, Lychnothamnus barbatus, found in Lake Rogóźno in 1964, and N. capillaris, found near Krasnobród, were added. In 1956, two new species of charophytes were reported from Lubelszczyzna: C. braunii and C. filiformis (Karczmarz and Malicki 1965); the authors concluded that in total 21 species of charophytes can be found in Lubelszczyzna. More results of ecological investigations and distribution data of charophytes as well as their communities have been published by Dąmbska (1960, 1966), Karczmarz (1966, 1980) and Karczmarz and Malicki (1971). Recently several aquatic plant researchers have investigated the Lubelszczyzna region and added new data to our knowledge on the charophyte flora (Ciecierska 2001; Urbaniak et al. 2008).

The aim of this paper is to review the pattern of charophyte flora in Lubelszczyzna and to summarize its occurrence as a result of long and intense field investigation and revision of herbaria specimens. 


\section{MATERIAL AND METHODS}

Lubelszczyzna is situated in the eastern part of Poland, close to the Ukrainian and Belarus border, and includes more than 200 lakes, many ponds, drainage channels, small rivers, and peatlands - possible habitats for the abundant flora of water plants. An investigated part of the Lubelszczyzna region is located between the Wisła and Bug rivers and belongs to the Lubelskie Voivodeship.

The maps of the charophyte species distribution in Lubelszczyzna region were prepared on the basis of field investigations done between 2003 and 2009, literature data, and herbaria collections. We have examined the specimens from the following herbaria (acronyms according to Holmgren and Holmgren (1998): the Herbarium Department of Botany and Mycology Institute of Biology, University Maria Curie Skłodowska, Lublin (LBL); Izabela Dąmbska Collection placed in the Department of Hydrobiology, Adam Mickiewicz University, Poznań; Museum of Natural History, University of Wrocław (WRSL, BRSL); and the author's own collection placed in the Department of Botany and Plant Ecology, Wrocław (J.U.); the Department of Ecology, Lublin (P.S.); and the Department of Hydrobiology, Poznań (M.G.); altogether more than 690 specimens were examined. Additionally, about 100 literature data were added to a database.

The determination of the specimens was carried out by the authors based on Krause (1997) and followed his nomenclature. In the cases of $N$. flexilis and N. opaca, correct determination of some of the collected sterile specimens was not possible; they could be included in either species. For this reason, we have decided to present additional figures with undetermined specimens that could probably belong to one of these two species.

The $2 \times 2 \mathrm{~km}$ ATPOL grid square system was used for the preparation of the distribution map (Zając 1978). During preparation of the maps, the herbaria specimens had priority in presentation. However, if no specimen was present in the collection, the literature data presented on the maps were used.

\section{RESULTS}

It follows from over 690 records collected that flora of the Lubelszczyzna region encompasses 22 species of charophytes (Fig. 1, Table 1). They represent four of the five genera of charophytes found in Poland: Chara (13 species), Nitella (7 species), Nitellopsis (1 species), and Lychnothamnus (1 species).

Charophytes were found in numerous sites in the whole territory of Lubelszczyzna. C. globularis is the most common species in the region (27.4\% frequency). For three species: C. intermedia, $C$. vulgaris, and C. delicatula, more than 60 records were noted with frequencies of $9.2-16.3 \%$. Eight species are rare; their frequency of occurrence does

TABLE 1. Ecological requirements, species frequency and red list of charophytes in the the Lubelszczyzna region.

\begin{tabular}{|c|c|c|c|c|c|c|c|c|c|c|}
\hline \multicolumn{7}{|c|}{ Number of records within different types of water habitats } & \multicolumn{2}{|c|}{ Frequency } & \multicolumn{2}{|c|}{ Threats categories } \\
\hline & 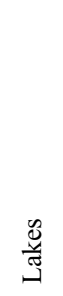 & $\begin{array}{l}\frac{\infty}{0} \\
8 \\
0 \\
0 \\
0 \\
0 \\
0\end{array}$ & 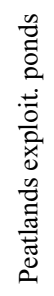 & 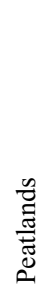 & $\frac{\mathscr{d}}{\frac{\tilde{e}}{0}}$ & 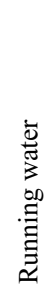 & 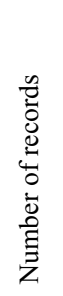 & 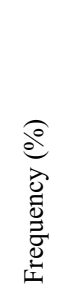 & 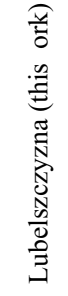 & 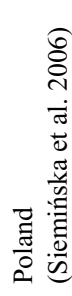 \\
\hline Chara aspera & 10 & & & & & & 10 & 1.4 & $\mathrm{EN}$ & $\mathrm{E}$ \\
\hline Chara braunii & & 5 & & & & & 5 & 0.7 & $\mathrm{EN}$ & $\mathrm{E}$ \\
\hline Chara contraria & 21 & 1 & 3 & 1 & 1 & 1 & 28 & 4.0 & VU & $\mathrm{V}$ \\
\hline Chara crassiacaulis & & & & 2 & 1 & & 3 & 0.4 & $\mathrm{CR}$ & I \\
\hline Chara delicatula & 43 & 1 & 11 & 5 & 4 & & 64 & 9.2 & & $\mathrm{~V}$ \\
\hline Chara globularis & 124 & 23 & 24 & 6 & 12 & 1 & 190 & 27.4 & & V \\
\hline Chara hispida & 15 & 2 & 7 & & & & 24 & 3.9 & & $\mathrm{E}$ \\
\hline Chara intermedia & 74 & 4 & 18 & 12 & 6 & & 113 & 16.3 & VU & $\mathrm{E}$ \\
\hline Chara rudis & 23 & 1 & & & & & 24 & 3.5 & EN & V \\
\hline Chara tenuispina & 1 & & 1 & 1 & & & 3 & 0.4 & $\mathrm{CR}$ & $\mathrm{E}$ \\
\hline Chara tomentosa & 14 & & & & & & 14 & 2.0 & VU & $\mathrm{R}$ \\
\hline Chara vulgaris & 25 & 23 & 14 & 8 & 11 & & 81 & 11.6 & & $\mathrm{~V}$ \\
\hline Nitella capillaris & & 1 & & 1 & & & 2 & 0.3 & $\mathrm{CR}$ & I \\
\hline Nitella flexilis & 22 & & & & & & 22 & 3.2 & & V \\
\hline Nitella gracilis & & 1 & & & & & 1 & 0.1 & $\mathrm{CR}$ & I \\
\hline Nitella mucronata & 19 & 3 & & & & & 21 & 3.0 & VU & $\mathrm{E}$ \\
\hline Nitella opaca & 1 & & & & & & 1 & 0.1 & $\mathrm{CR}$ & I \\
\hline Nitella syncarpa & 16 & 3 & 2 & & 3 & & 25 & 3.6 & EN & I \\
\hline Nitella tenuissima & & & & & 1 & & 2 & 0.3 & $\mathrm{CR}$ & I \\
\hline Lychnothamnus barbatus & 16 & & 1 & 1 & & & 17 & 2.5 & $\mathrm{CR}$ & $\mathrm{E}$ \\
\hline
\end{tabular}




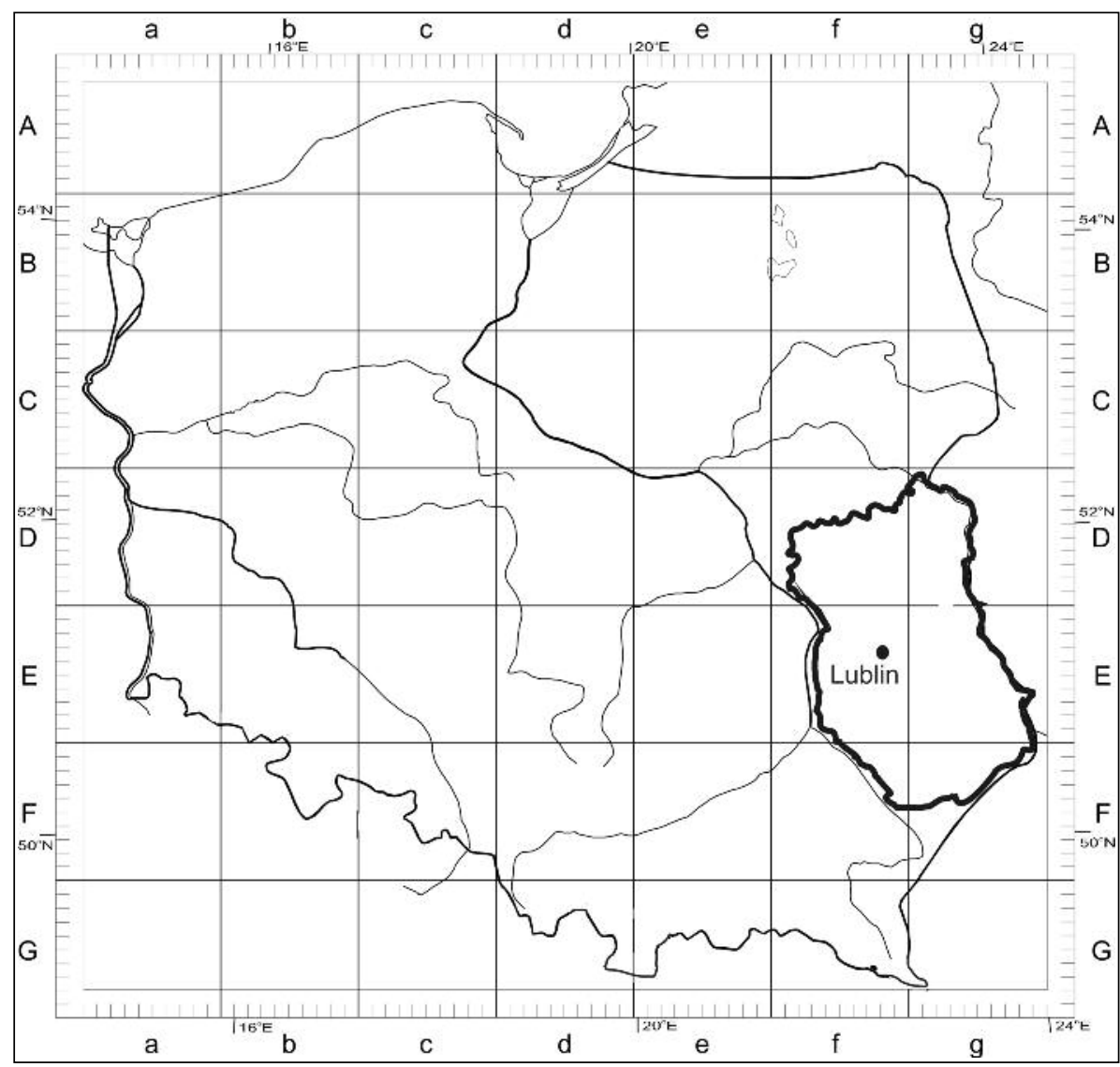

Fig. 1. Localization of the study area in Poland. not exceed $1 \%$ (> 15 records): C. braunii, C. crassicaulis, C. filiformis, C. tenuispina, $N$. capillaris, $N$. gracilis, $N$. opaca, and N. tenuissima (Table 1).

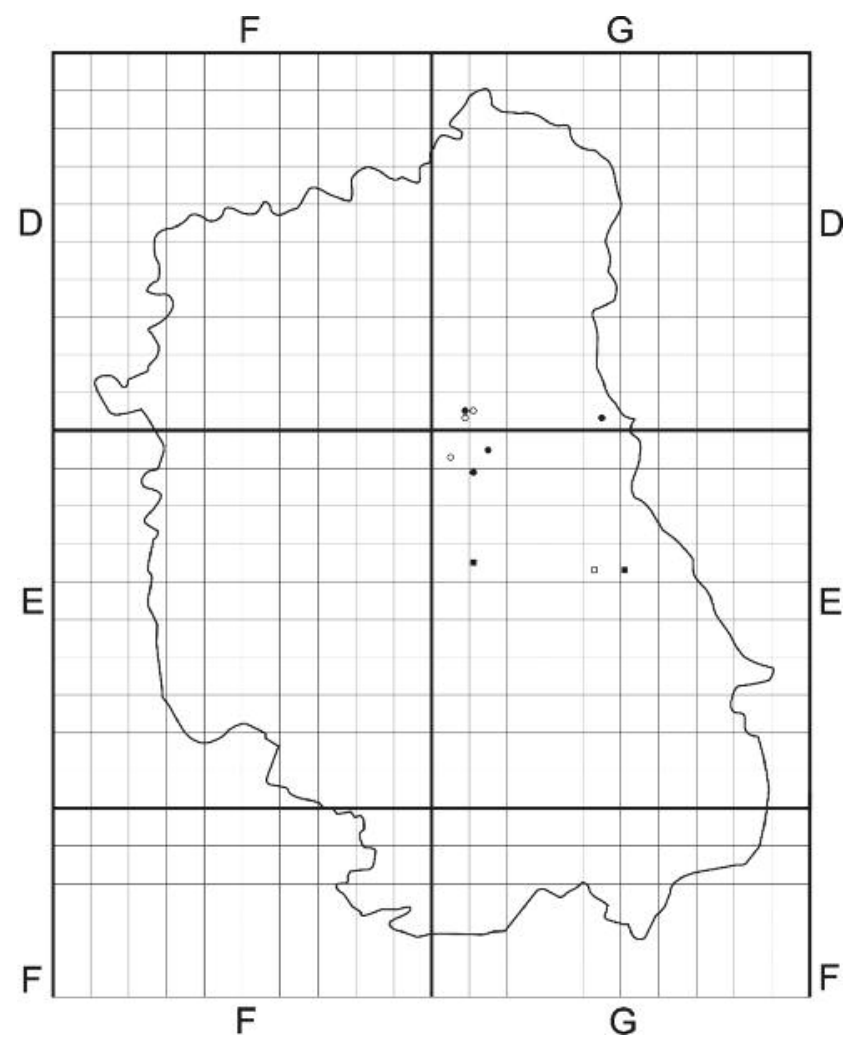

Fig. 2. Distribution of Chara aspera (circle) and Chara crassicaulis (square) in Lubelszczyzna region. Filled figures - single sites of own observation or from herbarium, empty figures - literature data. All figures are described in the same way.

\section{SPECIES AND THEIR DISTRIBUTION}

Chara aspera Detharding ex Willdenow 1809

In the Lubelszczyzna region, $C$. aspera is found only in lakes on sandy or sandy-muddy bottoms. Most records are from sheltered sites, for example shallow bays or shallow, sheltered lagoons, but the species can be found down to 4 (5) $\mathrm{m}$ (Lake Białe). This species has been found scattered throughout the region (Fijałkowski 1959; Karczmarz 1963, 1965) in seven different localities, in lakes (Fig. 2). It has not been recorded in Lubelszczyzna since 1980.

Chara braunii Gmelin 1826

This species is known from two localities found in the central part of the region (Fig. 3) in the last century (Karczmarz 1966). It occurs in fish pond farms on the clay bottom with clear water. All the records are from shallow water of up to $0.5(0.75) \mathrm{m}$ depth.

\section{Chara contraria A. Braun ex Kützing 1845}

C. contraria grows in Lubelszczyzna in a wide range of habitats, such as lakes, peatland exploitation ponds, ditches, ponds, pools, canals, and rivers (Karczmarz 1965, 1966; Karczmarz and Malicki 1971). C. contraria is in most cases found on sand or on muddy-sandy substrates. Depths range from 0.2 to $5 \mathrm{~m}$, but most records are from 0.5 to $2 \mathrm{~m}$ (Fig. 4).

Chara crassicaulis Schleicher 1821

This species was found in the central part of the region in hollows on the calcareous fen near Dorohucza and in a ditch close to a cement mill near Chełm (Karczmarz 1965) (Fig. 2). The species was found in shallow and very shallow water on the muddy bottom (probably calcareous gyttja). 


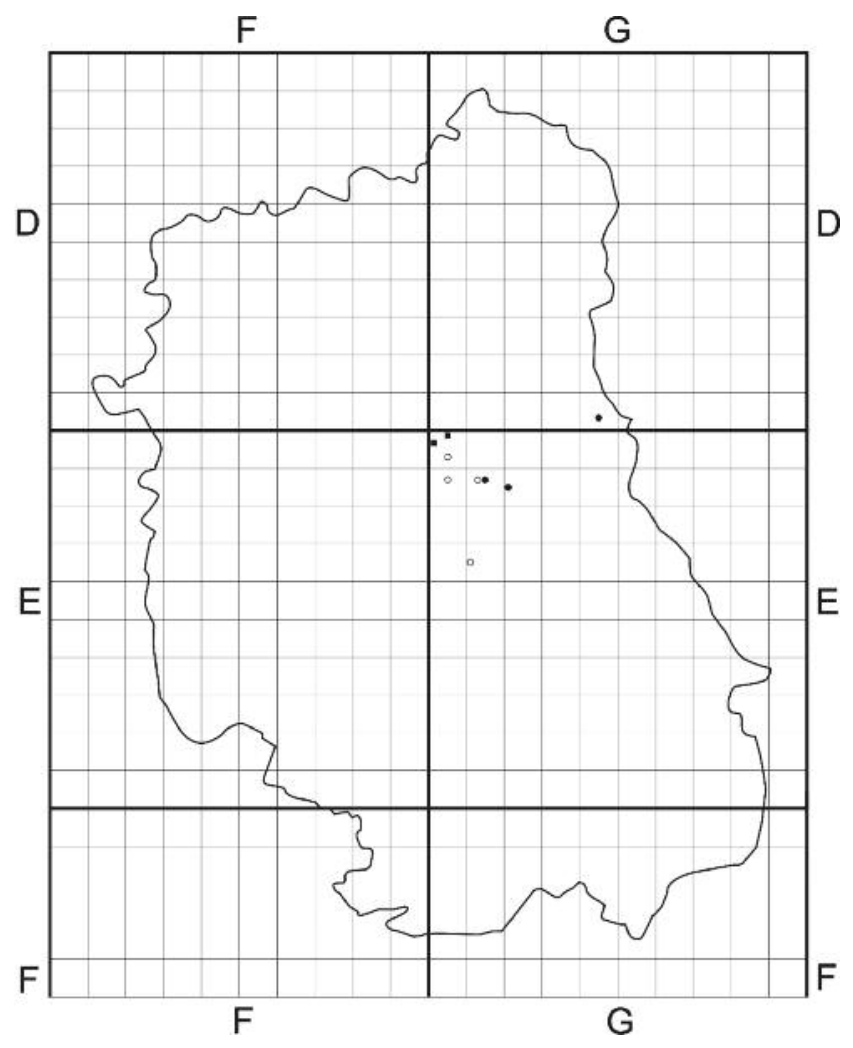

Fig. 3. Distribution of Chara braunii (square) and Chara rudis (circle) in Lubelszczyzna region.

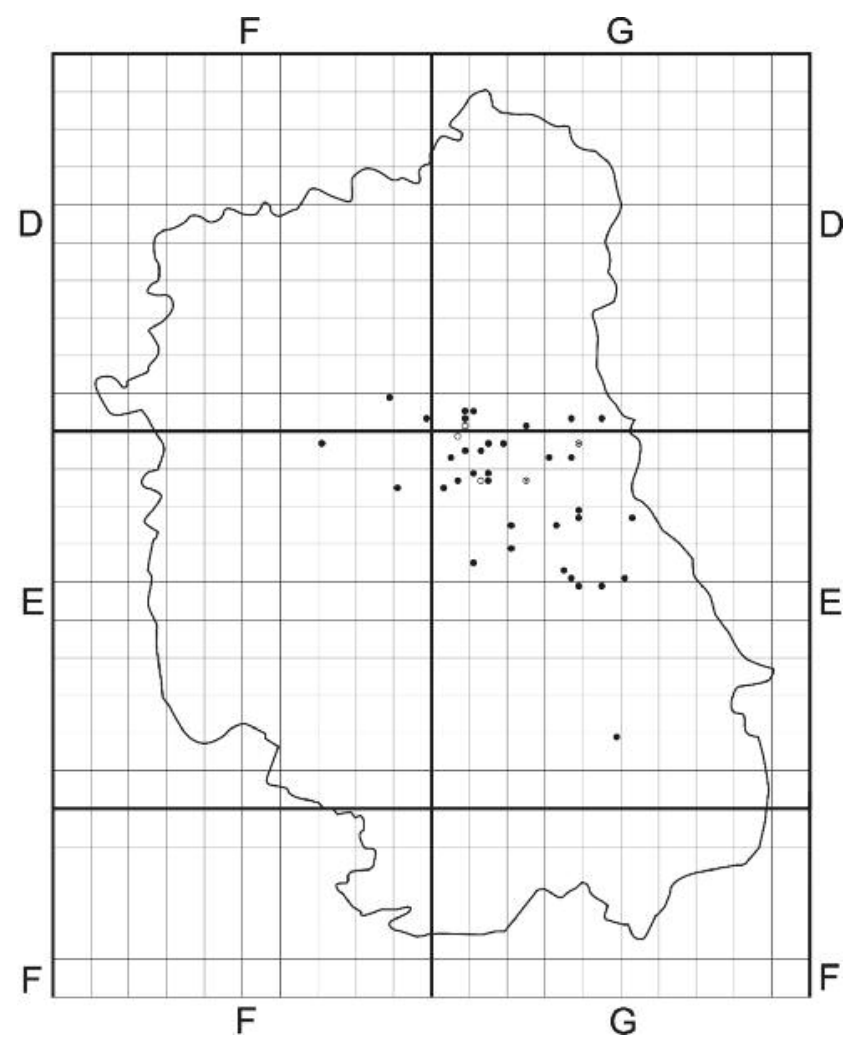

Fig. 5. Distribution of Chara delicatula in Lubelszczyzna region.

\section{Chara delicatula Agardh 1824}

C. delicatula was commonly found in different types of water ecosystems, but the area of particularly common occurrence is the Łęczyńsko Włodawskie Lakeland (Fijałkowski 1959; Karczmarz 1966, 1973) in the central part of Lubel-

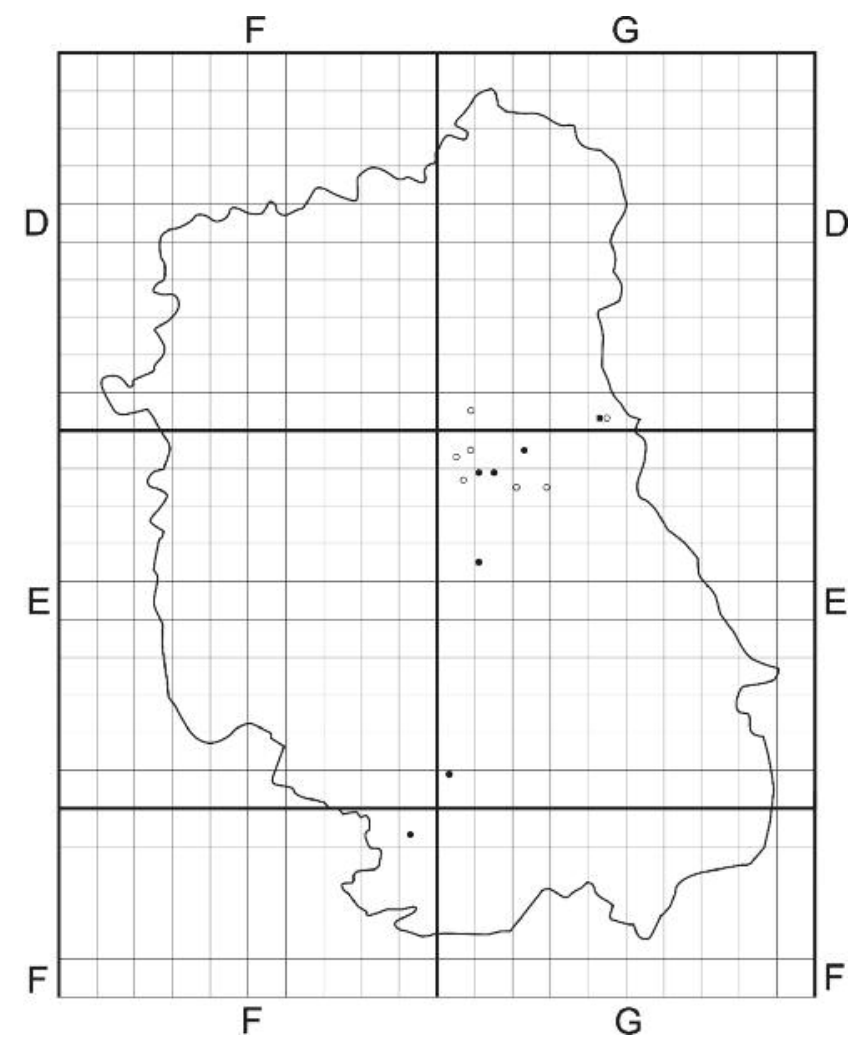

Fig. 4. Distribution of Chara contraria (circle) and Chara filiformis (square) in Lubelszczyzna region.

szczyzna (Fig. 5). The species was found in peatland exploitation ponds and ponds and ditches with sandy (lakes) or silty (ponds) bottoms. It was usually recorded at shallow water sites (depth 0.2-0.5 m) or in deeper parts of lakes $(5 \mathrm{~m}$ depth, Lake Białe near Włodawa, in waters with a neutral $\mathrm{pH}$ ).

\section{Chara filiformis Hertzsch 1855}

C. filiformis is known from only one locality, Lake Białe by Karczmarz and Malicki (1965) (Fig. 4). The species was found in deep water of about $6 \mathrm{~m}$ depth together with $C$. rudis and C. globularis.

\section{Chara globularis Thuillier 1799}

C. globularis is distributed in very different habitats, and similarly to the case of $C$. delicatula, $C$. globularis grows in ponds, ditches, peat pits, pools, slow-moving canals, ditches, and lakes (Fig. 6). Organic mud and clay are the preferred substrates, but the species was also reported on sandy and hard bottoms (Fijałkowski 1959; Karczmarz $1963,1965,1966)$. The majority of the findings are from shallow water: $0.1-1.5 \mathrm{~m}$ (ponds, ditches, peats) and the maximum depth ranges observed in the Lubelszczyzna region were 2-6 m, in Lake Rogóźno near Łęczna.

\section{Chara hispida Linnaeus 1753}

This is not an especially common species in Lubelszczyzna (Karczmarz 1963, 1966; Karczmarz and Malicki 1965) and is located mainly in the central part of the region in the area of Łęczyńsko-Włodawskie Lakeland (Fig. 7). Most findings of $C$. hispida in Lubelszczyzna are from peat pits and lakes, but the species also occurs in ponds and ditches with slow moving water. Clay and organic mud are the preferred substrates. It is usually recorded at depths of $0.2-3 \mathrm{~m}$ in waters with a neutral $\mathrm{pH}$. 
$\mathrm{F}$

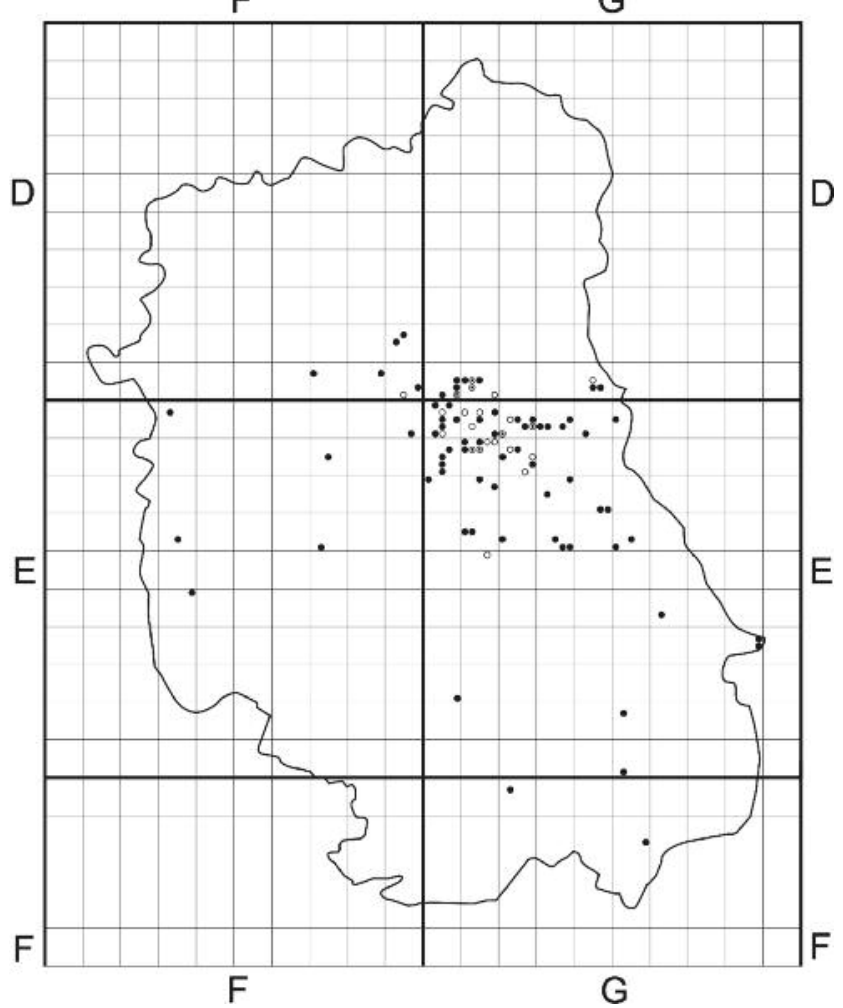

Fig. 6. Distribution of Chara globularis in Lubelszczyzna region.

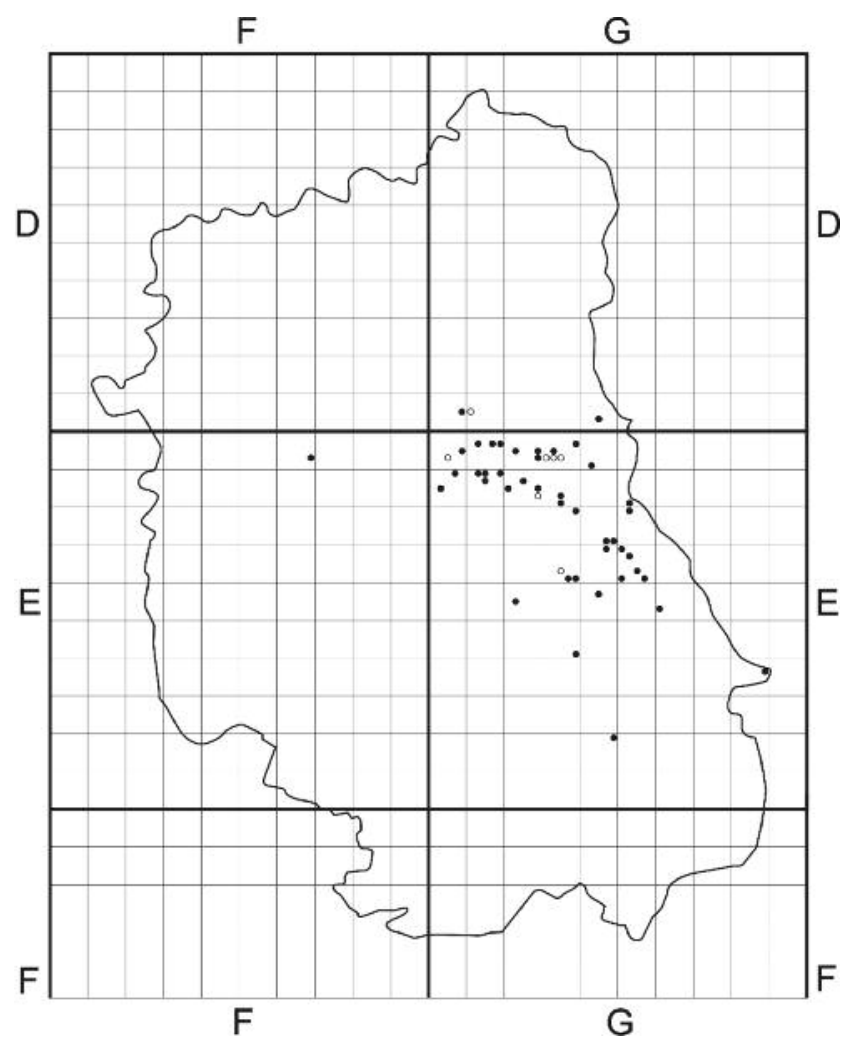

Fig. 8. Distribution of Chara intermedia in Lubelszczyzna region.

\section{Chara intermedia A. Braun 1836}

According to the herbaria material, $C$. intermedia is common in Lubelszczyzna (Fig. 8). The species is found in many types of habitats like eutrophic or mesotrophic lakes (mostly in the central part of the region) in calcareous peat-

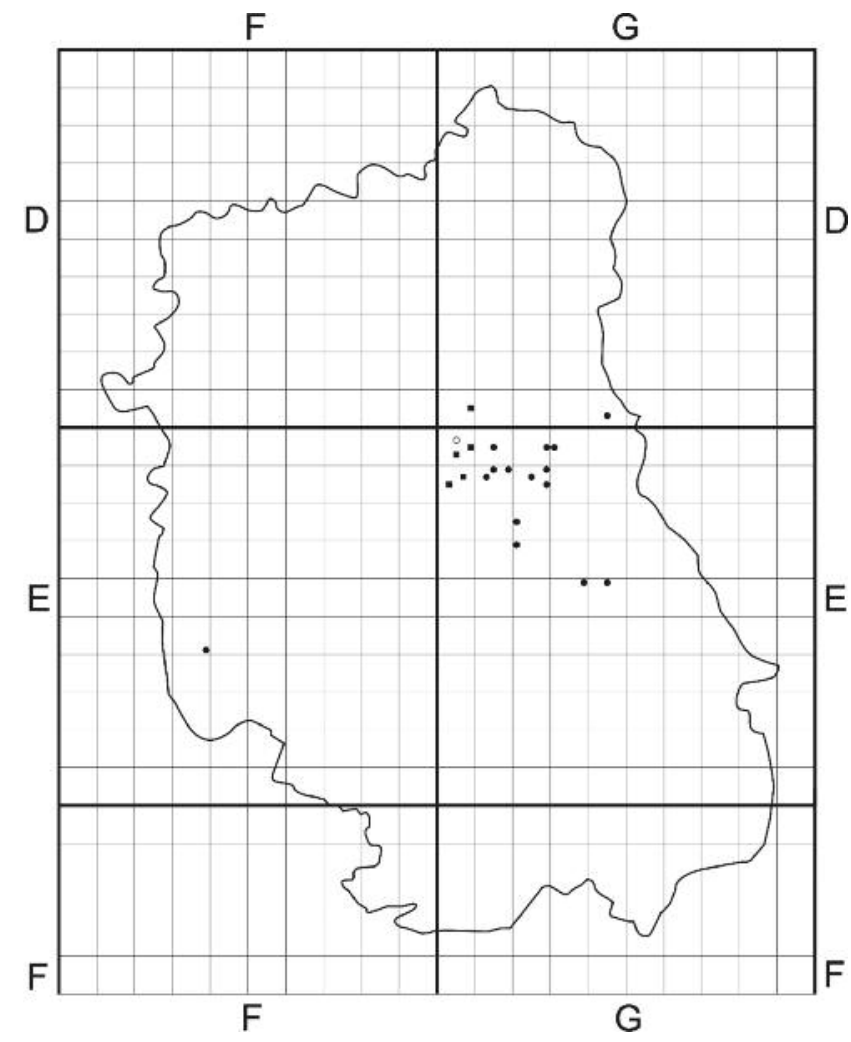

Fig. 7. Distribution of Chara hispida (circle) and Lychnothamnus barbatus (square) in Lubelszczyzna region.

land exploitation ponds or canals, in alkaline water (Fijałkowski 1959; Karczmarz 1963, 1965; Karczmarz and Malicki 1965). This species is recorded mostly from very shallow terrestric mid-forest lakes. Its sites in the lakes with neighbouring peatlands are particularly numerous. The bottom substrate varies from silt and calcareous gyttja to sand and gravel. $C$. intermedia has been collected from shallow water $(0.3 \mathrm{~m})$ down to $3 \mathrm{~m}$.

Chara rudis A. Braun in Leonhardi 1882

The species has been found scattered throughout the region in only seven different localities (Fig. 3). The majority of the findings of $C$. rudis from Lubelszczyzna are from lakes, with the exception of two localities: one is located in peat pits near Hańsk and the second in a fish ponds close to Sosnowa Wola (Karczmarz 1963, 1965, 1966; Karczmarz and Malicki 1971). Organic mud or calcareous gyttja are the preferred substrates in water rich in calcium. The species was recorded in shallow water and in lakes from 1.5 to $5 \mathrm{~m}$ in depth.

\section{Chara tenuispina A. Braun 1835}

The species is known from several localities: near the shoreline of Lake Bartków and two localities on the calcareous fen near Chełm (Fig. 9). Most frequently, $C$. tenuispina appeared at low water depths on organic substrates rich in calcium. In summertime, the depth of the water did not exceed $0.3 \mathrm{~m}$. The species grows among moss vegetation. $C$. tenuispina has been found on the muddy bottom or on the calcareous gyttja in shallow water of up to $0.5-1 \mathrm{~m}$ depth. 


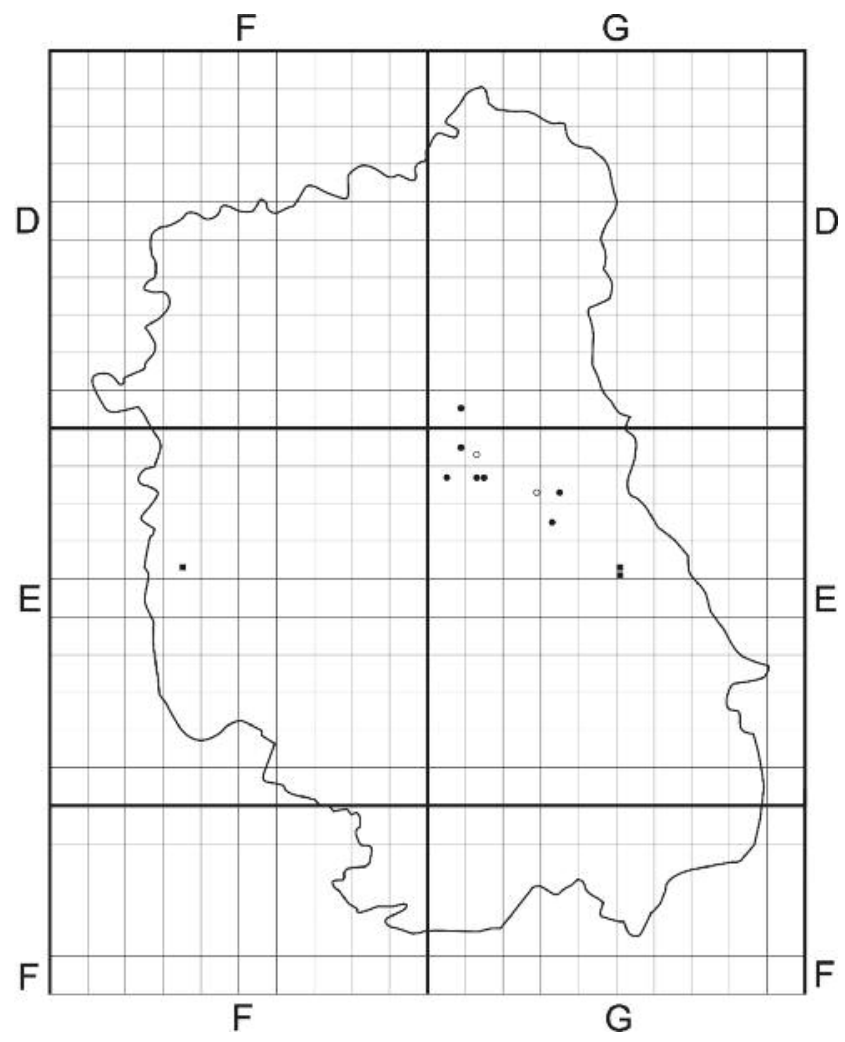

Fig. 9. Distribution of Chara tomentosa (circle), Chara tenuispina (square) in Lubelszczyzna region.

$\mathrm{F}$

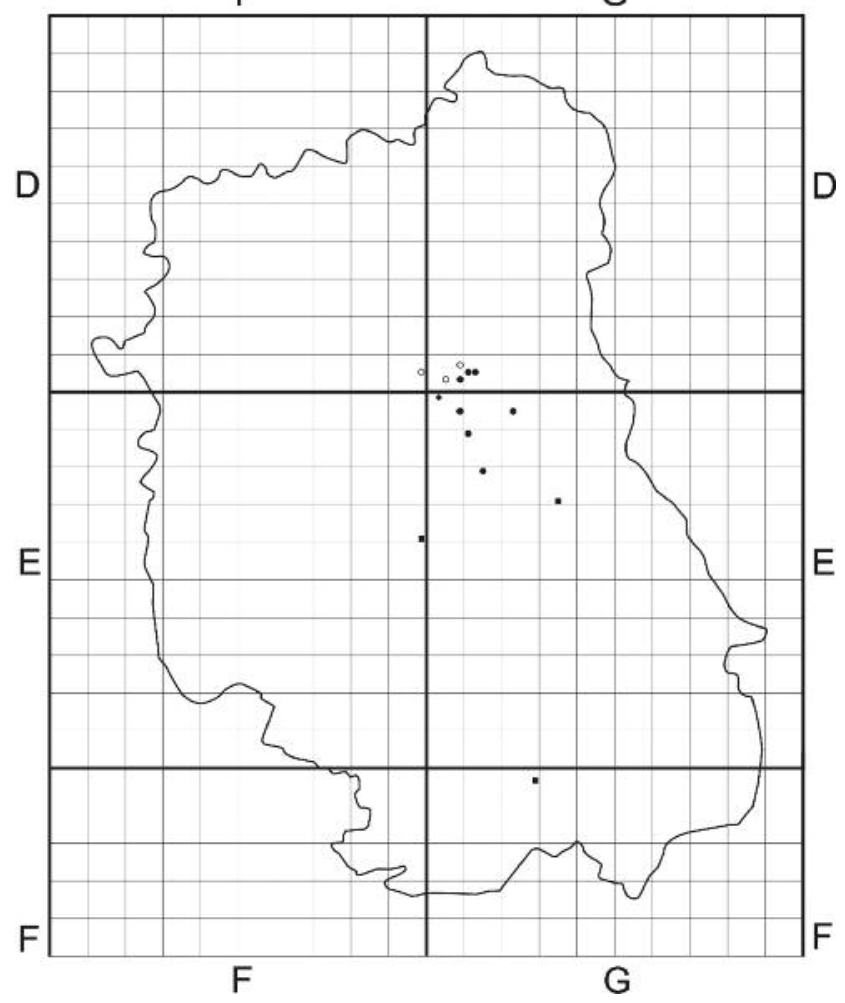

Fig. 11. Distribution of Nitella capillaris (square), Nitella gracilis (diamond) and Nitella mucronata (circle) in Lubelszczyzna region.

\section{Chara tomentosa Linnaeus 1753}

C. tomentosa was recorded only from lakes (nine localities), where the plants form dense stands (Fijałkowski 1959; Karczmarz 1963) (Fig. 9). Most of the herbaria findings come from silty or muddy bottoms, which are the pre-

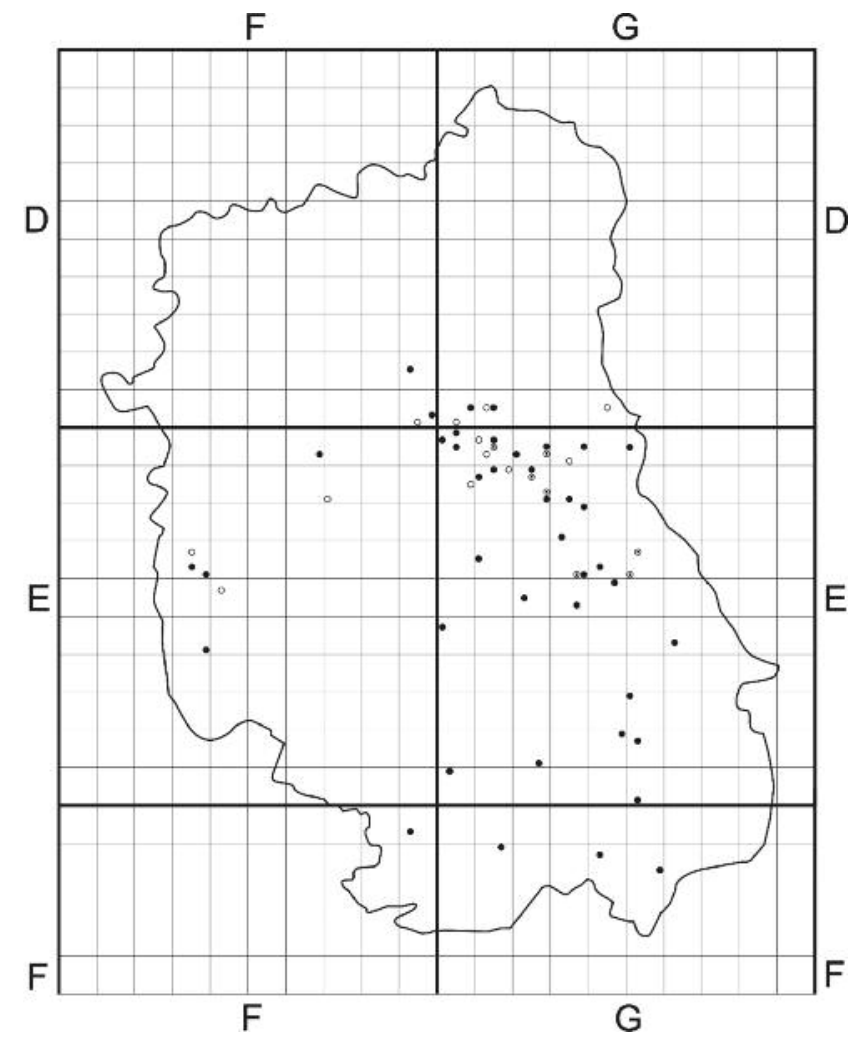

Fig. 10. Distribution of Chara vulgaris in Lubelszczyzna region.

ferred substrates. The majority of the records are from 0.5 to $3.0 \mathrm{~m}$; the maximum depth ranges observed were $5 \mathrm{~m}$.

\section{Chara vulgaris Linnaeus 1753}

C. vulgaris together with $C$. globularis is the most common species in the Lubelszczyzna region, with the widest ecological amplitude (Fig. 10). It has been recorded in a wide range of habitats such as lakes, streams, rivers, ephemeral water bodies, peat pits, ditches, puddles, slowmoving canals, man-made habitats, and recently disturbed sites that may hold a little rain or ground water (Fijałkowski 1959; Karczmarz 1963, 1965, 1966; 1975). The species has been recorded from depths of 0.2 to $2.5 \mathrm{~m}$. It occurs mainly on muddy bottoms and clay or sand covered by muddy organic deposits.

\section{Lychnothamnus barbatus (Meyen) Leonhardi 1863}

This is a rare species which is known from only five localities (Fig. 7). All are in lakes with the exception of one locality in old peat pits near Ludwin, where the species was found recently at about $1 \mathrm{~m}$ depth on a silt bottom (Kraczmarz 1965; Karczmarz and Krause 1979; Sugier et al. 2009). L. barbatus has been recorded in slightly alkaline mesotrophic and eutrophic water, from a depth of 1 to 4 (5) $\mathrm{m}$.

\section{Nitella capillaris (Krocker) J. Groves and Bullock-Webster 1920}

$N$. capillaris is known from only two locations, both lakes: Uścimów and Zagłębocze (Fig. 11). The species was found in very shallow water up to $0.5 \mathrm{~m}$ depth on a clay bottom.

Nitella flexilis (Linnaeus) Agardh 1824

$N$. flexilis is known from several localities - all lakes in Łęczyńsko Włodawskie Lakeland (Fijałkowski 1959; Kar- 
$\mathrm{F}$

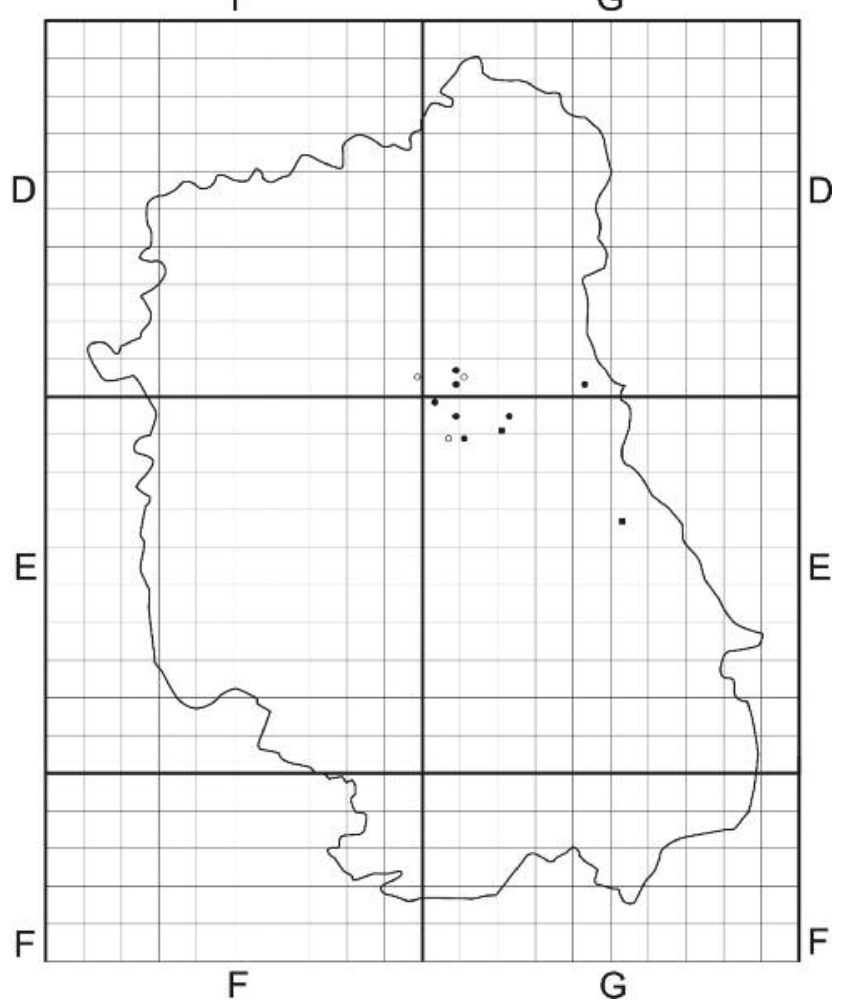

Fig. 12. Distribution of Nitella flexilis (circle) and Nitella tenuissina (square) in Lubelszczyzna region.

czmarz 1963, 1965, 1966) (Fig. 12). This species was recorded in shallow water of 0.3 to $1.0 \mathrm{~m}$ depth. The specimens in herbaria come from sandy or sand-clay bottoms, which are probably the preferred substrates.

Nitella gracilis (Smith) Agardh 1828

There is the only one known locality of $N$. gracilis in Lubelszczyzna (Fig. 11). This species has been found near Uścimów in sheltered water on soft substrates (clay, mud) in shallow water of up to $0.8 \mathrm{~m}$ depth.

\section{Nitella mucronata (A. Braun) Miquell 1840}

The species seems to be not particularly common in Lubelszczyzna (Fig. 11). The specimens of N. mucronata have been found in lakes and three have been found in fish ponds (Fijałkowski 1959; Karczmarz 1963). The findings are from water of 0.3 to $0.5 \mathrm{~m}$ in depth, on a soft, muddy bottom.

\section{Nitella opaca (Bruzelius) Agardh 1824}

N. opaca is widely distributed in Poland, but locally it is a very rare species. The only known locality of $N$. opaca is Lake Piaseczno (Fig. 13).

\section{Nitella syncarpa (Thuillier) Chevallier 1827}

$N$. syncarpa is not a particularly common species in the Lubelszczyzna region; to date a total of 16 localities of the species are known (Fig. 13). Almost all specimens came from lakes; four specimens were found in pits and ditches in peat bogs (Karczmarz 1963, 1965, 1973). It grows in sheltered water at a depth of 0.4-2.5 m on soft substrates such as organic mud or peat.

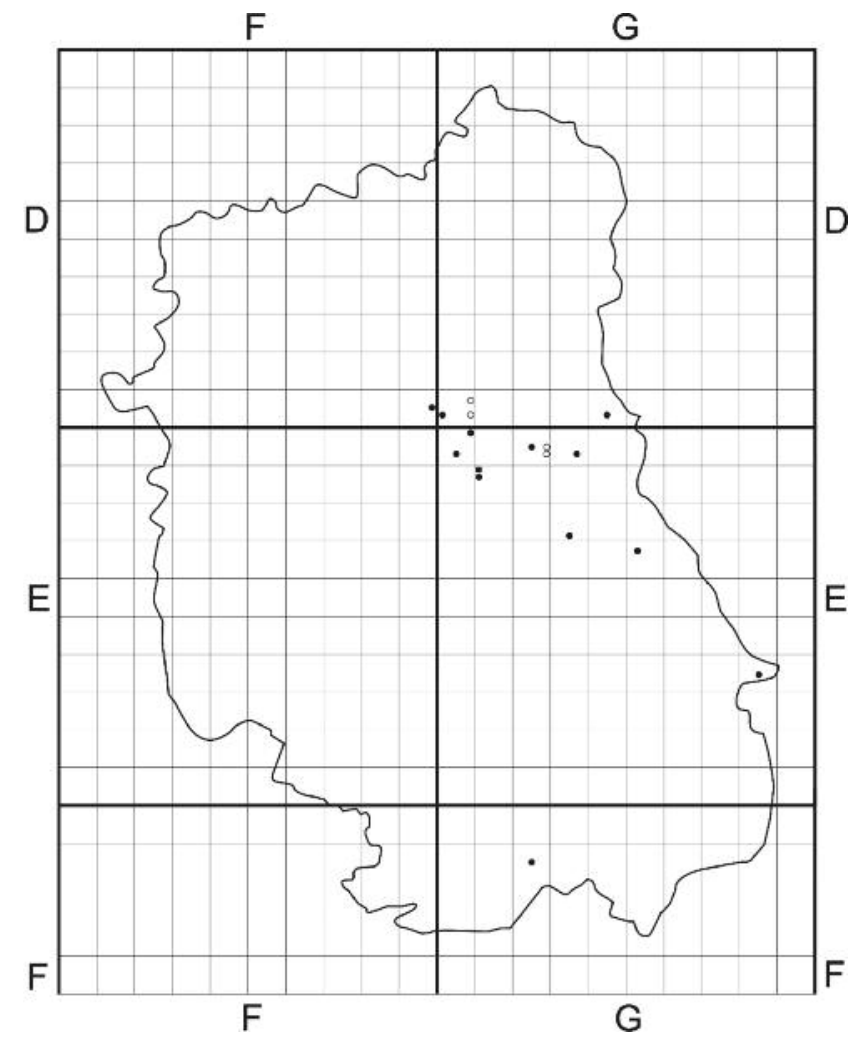

Fig. 13. Distribution of Nitella opaca (square) and Nitella syncarpa (circle) in Lubelszczyzna region.

Nitella tenuissima (Desvaux) Kützing 1843

N. tenuissima is one of the rarest plants of Lubelszczyzna (Fig. 12). The only two records known from Lubelszczyzna are from calcareous habitats in peat pits on a rich fen covered by Cladium mariscus in 1960 (peatland "Krowie Bagno") and in 2004 (peatland "Brzeźno") by Urbaniak et al. (2008). N. tenuisima was found in very shallow water of 0.3 to about $0.5 \mathrm{~m}$, on a soft, calcareous gyttja.

Nitellopsis obtusa (Desvaux in Loiseleur-Deslongchamps) J. Groves 1919

Almost all of the findings in Lubelszczyzna are from lakes and only are two from peat pits (Fijałkowski 1959; Karczmarz 1963; Karczmarz, Malicki 1965) (Fig. 14). Water depths ranged from 0.5 to $4 \mathrm{~m}$. The species was found on calcareous gyttja or muddy substrate, where it forms dense underwater meadows, especially in shallow lake bays.

\section{Nitella flexilis vel Nitella opaca}

In the description of the charophyte flora of the Lubelszczyzna region, we have decided to distinguish several specimens that were similar to $N$. flexilis or to $N$. opaca. None of them were fertile (oogonia and atheridia were lacking), which is one of the most important characteristics that allows correct determination. All were found in lakes at depths of 1-3 m on muddy bottoms (Fig. 14).

\section{DISCUSSION}

Important types of habitats of charophytes in the Lubelszczyzna region

C. globularis and C. vulgaris have the widest ecological amplitudes and, as written above, are the most common 
$\mathrm{F}$

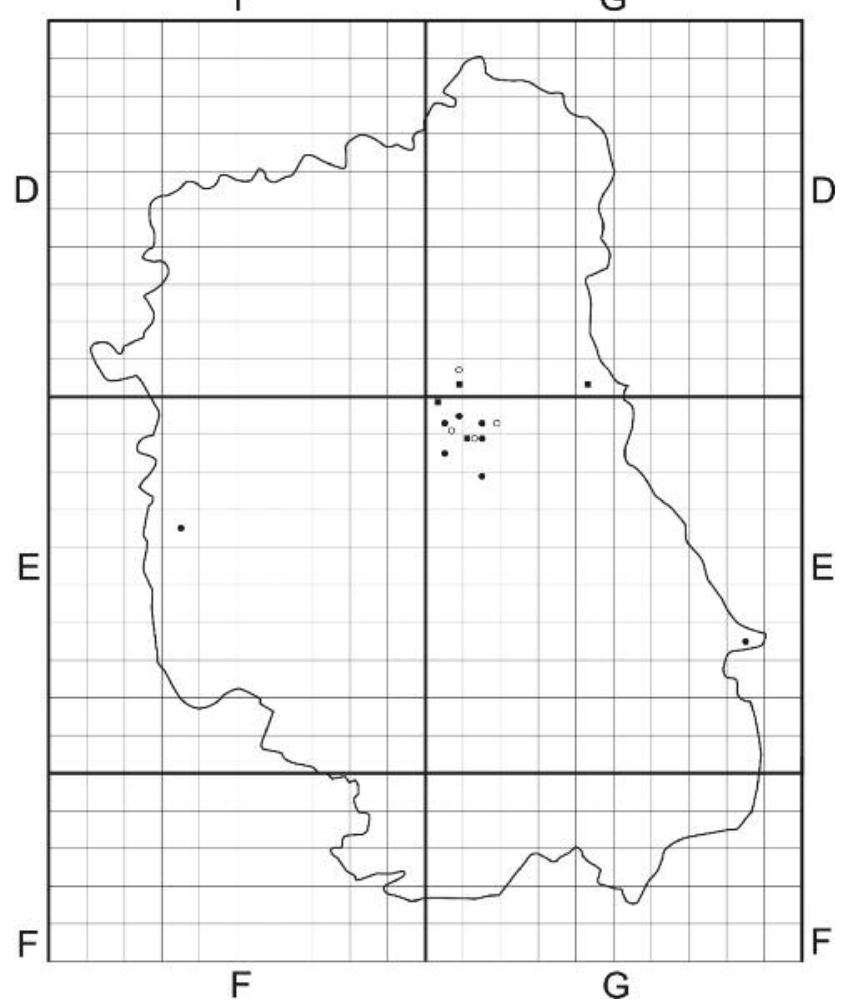

Fig. 14. Distribution of Nitellopsis obtusa (circle) and Nitella flexilis vel N. opaca (square) in Lubelszczyzna region.

species not only in Lubelszczyzna, but also in the whole of Poland. C. vulgaris growth especially is found in each kind of shallow water, for example in ponds, pools, peatland exploitation ponds, peatlands, and ditches as well as in pools and the littoral zones of lakes, but was rarely recorded in deeper lakes. Many specimens grow in anthropogenic reservoirs and temporary waters. According to Dąmbska (1964) C. delicatula is widely distributed, but not particularly common in Poland. Some authors suggest that $C$. delicatula can be found most often in "cold", large, oligotrophic, and Lobelia lakes and can indicate "oligotrophy" (Karczmarz 1973). This seems to be only partly true, because this species can be found not only in oligotrophic lakes. In humic, mesotrophic, and eutrophic calcium rich lakes where the water transparency is low, C. delicatula was found in shallow water of up to $0.5 \mathrm{~m}$. In deeper localities where $C$. delicatula can grow, water transparency seems to be the most important feature which determines its occurrence in water (Blindow 1992) not only in Lubelszczyzna but also in the other localities.

According to the herbaria material and literature data (Gąbka et al. 2007), C. intermedia is not particularly common in Poland in most of the country, where it grows in lakes, peat pits, or canals generally in highly alkaline water or rarely in calcium poor, humic water. Almost all findings in Lubelszczyzna (Fig. 8) come from lakes and peatlands and especially from the calcareous fens in Bagno Serebryskie, Brzeźno, and Roskosz natural reserves, where $C$. intermedia is very common. In Poland this species is recorded mostly in very shallow terrestric mid-forest lakes, particularly in lakes with neighbouring peat bogs (Gąbka 2007).

Both $N$. opaca and $N$. flexilis are widely distributed in Poland, but locally they are very rare species. $N$. opaca grows in a wide range of habitats, such as lakes, pits, pools, ditches, reservoirs, slow mowing water, and streams, being particularly common in alkaline water. In Lubelszczyzna, $N$. flexilis is not a very common species, while $N$. opaca is very rare.

N. mucronata can be found in a wide range of aquatic habitats (ponds, ditches, canals, and lakes). Most findings have been in Lubelszczyzna in water of 0.5 to $4.0 \mathrm{~m}$ in depth, with a maximum depth $(8.0 \mathrm{~m})$ recorded in Lake Leleskie (northern Poland). N. mucronata was mainly found on a soft, muddy bottom. It is not a particularly common species in Lubelszczyzna, and sometimes cannot be distinguished from another, similar one: $N$. gracilis which was found in only one locality in Lubelszczyzna (Urbaniak and Krawczyk 2008; Urbaniak 2009).

C. braunii is widespread in Poland, but is not particularly common. The species is well known from localities in large farm fish ponds. To date it has not been found in the northern part of Poland, but it can be expected there. More data on distribution as well as some details on the ecology of this species are summarized by Urbaniak (2007).

In Poland, $C$. crassicaulis is classified as a separate species (Dąmbska 1964), but other authors do not distinguish it from C. vulgaris, which is similar. This is one of the rarest species in the Lubelszczyzna region, and has been found mainly in alkaline water from limestone ditches on calcareous peatland exploitation ponds in eastern Poland (Karczmarz and Malicki 1965; Święs 1966). Other data from the Wielkopolska region suggested waters rich in $\mathrm{Ca}^{2+}, \mathrm{Na}^{+}, \mathrm{K}^{+}$, and $\mathrm{SO}_{4}{ }^{2-}$ (Gąbka 2004, 2009). Because of its rarity in Poland, the ecological requirements of C. crassicaulis are poorly known. But some details suggest that this species prefers strongly calcareous sites. The taxonomic status is still unclear and needs more detailed studies.

Many sites of L. barbatus have been destroyed by urban sprawl and drainage (Karczmarz and Krause 1979; Krause 1997). The research done during the past two decades has shown that the populations recorded in the past have tended to disappear due to eutrophication and tourist pressure (Balevičius 2001). On the other hand, new locations have been discovered in Polish lakes that were unexplored previously (Sugier et al. 2009). The most stable sites for $L$. barbatus in Poland are located in Lake Rogóźno, which is deep and shows little change in water levels (Sugier 2008). L. barbatus communities have been recorded at intervals over the past 50 years (Karczmarz and Malicki 1971; Karczmarz 1980; Ciecierska 2001; Sugier 2008). Such sites are of vital importance for the preservation of the species and for its potential future active conservation.

C. tenuispina is a rare species not only in Lubelszczyzna, but in Poland as well. It has been reported as a relatively rarely seen species, known from 19 sites (Gąbka 2007). In Lubelszczyzna only three sites have been found. C. tenuispina was mainly found in rich fens and peatland exploitation ponds. A small amount of detailed data point to the appearance of this charophyte in shallow-lake areas, probably in the $C$. mariscus zone. Most frequently, C. tenuispina appeared at low water depths on organic substrates rich in calcium. It is found in a wide spectrum of trophy and calcium contents. The species grows either among moss vegetation or on exposed lake deposits.

$N$. tenuissima is one of the rarest charophyte species that have been found in Lubelszczyzna; it is a rare plant with 
local occurrence, and the central and southern European distribution as well as some details on the ecology of this species is summarized by Urbaniak et al. (2008). Both localities are similar, and the species was found on a calcareous bottom at a depth of 0.3-0.7 m together with vascular plants. It is expected that $N$. tenuissima might be found in additional localities, close to the present ones.

In conclusion, the two species $C$. intermedia and $C$. vulgaris were more frequently found in Lubelszczyzna than in other parts of Poland: Kaszubske Lakeland (Bociąg 2006), Lubuskie Lake District (Pełechaty et al. 2007), Mazurske Lakeland (Hutorowicz and Dziedzic 1998), Śląsk (Urbaniak 2005), Wielkopolska region (Gąbka 2009), Sandomierska Valley (Urbaniak et al. 2010) and north eastern part of Poland (Urbaniak 2010a). Species like N. obtusa, C. tomentosa, $C$. aspera, and C. rudis were rare, whereas in other parts of Poland they are common. This could be a reason for differences between the origin, dimension, and trophic status of water ecosystems in Lubelszczyzna and those of the rest of the Polish lakelands (Radwan 1996). Many of the lakes, especially in Łączyńsko-Włodawskie lakeland, are deep and karstic in the area beyond the last glaciations. On the other side numerous peatlands, marshlands, shallow excavation water reserves, and overgrown lakes are commonly found. Because charophytes are an important indicator of trophic changes in the lakes and peatlands and their decline is related to vegetation changes, we decided to compare the charophyte flora in the Lubelszczyzna region with that in other parts of Poland.

\section{Threat categories and temporal changes of charophytes flora}

It is commonly known that the nutrient content in water, calcium concentration, and light availability as well as climatic conditions are important factors for charophyte occurrence. Charophytes are not only delimited to waters with low nutrient content (Forsberg 1964). This can be confirmed by the charophyte flora in Lubelszczyzna, where the plants can be found in almost all types of trophic statuses of water: oligotrophic, mesotrophic, eutrophic, and humic lakes. The lakes are the most common water reservoirs in Lubelszczyzna, and are located mainly in the Łęczyńsko Włodawskie Lakeland (the central part of the region) and in the Poleski National Park. The charophyte flora is not only restricted to the lakes. Some of the species are located in peat bogs, water-drainage channels, fish ponds, and different ephemeral water bodies.

On the basis of the determined frequency of occurrence of species in the Lubelszczyzna region and changes in the frequency of occurrence with time, we can differentiate four categories (Table 1): (1) common species, not endangered: $C$. delicatula, C. globularis, C. hispida, C. vulgaris, and N. flexilis; (2) endangered species (VU): C. contraria, C. intermedia, C. tomentosa, N. mucronata, and N. obtusa; (3) endangered species (EN): C. aspera, C. braunii, C. filiformis, C. rudis, and N. syncarpa; (4) rare, critically endangered species (CR): C. crassiacaulis, C. tenuispina, $N$. capillaris, $N$. gracilis, N. opaca, N. tenuissima, and L. barbatus.

Some of the species have declined from localities in the last 40 . The decline can be a natural process in the succession of lakes or can be due to still growing anthropogenic pressure, for example the presence of numerous drainage channels that cause decreases of the ground and lake water levels and increases in their trophic statuses. In many lakes, overgrowth of the littoral and changes in their areas are observed. This process is reinforced by changes of land use surrounding the lakes.

In the hydrogenic areas of mid-eastern Poland, the hydrological conditions were highly transformed by the Wieprz-Krzna canal. In many cases the function of lakes was transformed to that of retention reservoirs. Some charophytes declined (Karczmarz 1965). In hydrobiological lake studies conducted during the last five years in the Łęczna-Włodawa Lakeland, no Nitella species was observed. In the climatic conditions of mid-eastern Poland the freezing of the whole shallow phytolittoral zones of the lakes can be a reason for the disappearance of charophytes (Karczmarz 1980; Sugier 2001). The field studies in the last years did not confirm the occurrence of protected species such as $C$. crassicaulis and $N$. syncarpa in the chosen peat pits noted by Karczmarz $(1965,1966)$, where the disappearance might be connected with the entrance of helophytes and terrestrialization (Sugier et al. 2009). On the other hand new water bodies (ponds, retention reservoirs) have been created. They play a special role as potential habitats for quickly colonizing charophytes.

Additionally, there is substantial need for new observations, collections, and especially field and laboratory investigations of charophytes not only in Lubelszczyzna but in the whole of Poland. This could be helpful in detailed projections of tendencies in the disappearance of charophyte flora. Field studies could be very important for the preservation of mainly the rare species and for their potential active future conservation.

\section{ACKNOWLEDGEMENTS}

The authors are grateful to all the curators of the herbaria for help in collecting the data. This study was financially supported by the Polish Ministry of Science and Higher Education, project number N N303 506238 (J. Urbaniak).

\section{LITERATURE CITED}

BALEVIČIUS A. 2001. Distribution of Lychnothamnus barbatus community in Lithuania. Biologija 2: 70-73.

BLINDOW I. 1992. Decline of Charophytes during eutrophication: Comparison to angiosperms. Freshwater Biol. 28: 9-14.

BOCIĄG K. 2006. Distribution and abundance of stoneworts (Charales) in the Kashubian Lakeland (NW Poland) - data collected so far and some implications. Biodiv. Res. Conserv., 3-4: 90-95.

CIECIERSKA H. 2001. Vegetation of lakes in Łęczna-Włodawa Lake District as an example of landscape. Ekológia (Bratislava) 20 (4): 355-365.

COOPS H. 2002. Ecology of Charophytes: an introduction. Aquat. Bot. 71: 205-208

DĄMBSKA I. 1960. Charotheca Polonica, Fasc. VI, Nr 101-120, Characeae Regions Lublinensis. Poznań, PAN, pp. 1-8.

DĄMBSKA I. 1964. Charophyta - ramienice. Flora słodkowodna Polski. 13, pp. 1-126. PWN, Warszawa. (in Polish)

DĄMBSKA I. 1966. Zbiorowiska ramienic Polski. Poz. Tow. Przyj. Nauk. Prace Kom. Biol, 31: 1-75. (in Polish)

FIJAŁKOWSKI D. 1959. Szata roślinna jezior Łęczyńsko-Włodawskich i przylegających do nich torfowisk. Ann. Univ. M. Curie-Skłodowska, Sec. B 14 (3): 131-206. (in Polish with English summary) 
FORSBERG C. 1964. Phosphorus, a maximum factor in the growth of Characeae. Nature 201: 517-518.

GABBKA M. 2004. Chara crassicaulis Shleicher (Characeae) pierwsze stanowisko w Wielkopolsce. Bad. Fizjogr. Pol. Zach. Ser. B. 53: 81-85. (in Polish)

GĄBKA M. 2007. Distribution of Chara tenuispina A. Braun 1835 (Characeae) in Poland. Oceanological and Hydrobiological Studies 36 (1): 241-248.

GĄBKA M. 2009. Charophytes of the Wielkopolska region (NW Poland): distribution, taxonomy and autecology. pp. 1-109. Bogucki Wydawnictwo Naukowe, Poznań.

GĄBKA M., OWSIANNY P.M., BURCHARDT L., SOBCZYŃSKI T. 2007. Habitat requirements of the Charetum intermediae phytocoenoses in lakes of western Poland. Biologia, 62: 657-663.

GĄBKA M., PEŁECHATY M. 2006. Zagadnienia klasyfikacji taksonomiczneji synekologicznej ramienic (Characeae, Charophyta) i ich zbiorowisk. Ekologia i Technika XIV (3): 87-92. (in Polish with English summary)

HOLMGREN P.K., HOLMGREN N.H. 1998. Index Herbariorum: A global directory of public herbaria and associated staff. New York Botanical Garden's Virtual Herbarium. http://sweet gum.nybg.org/ih/

HUTOROWICZ A., DZIEDZIC J. 1998. Historyczne i współczesne stanowiska ramienic $\mathrm{w}$ jeziorach Pojezierza Olsztyńskiego. Fragm. Flor. Geobot. Ser. Polonica, 5: 279-291. (in Polish)

KARCZMARZ K. 1963. Przyczynek do badań nad florą ramienic Lubelszczyzny (Polska wschodnia). Cz. I. Acta Soc. Bot. Pol. 32 (1): 165-169. (in Polish with English summary)

KARCZMARZ K. 1965. Przyczynek do badań nad florą ramienic Lubelszczyzny (Polska wschodnia). Cz. II. Acta Soc. Bot. Pol. 34 (3): 385-388. (in Polish with English summary)

KARCZMARZ K. 1966. Przyczynek do badań nad florą ramienic Lubelszczyzny (Polska wschodnia). Cz. III. Acta Soc. Bot. Pol. 35 (2): 265-271. (in Polish with English summary)

KARCZMARZ K. 1973. Wymagania ekologiczne Chara delicatula. Ann. UMCS, sect. C, 28: 117-123. (in Polish with English summary)

KARCZMARZ K. 1980. Strefowość rozmieszczenia ramienic w głębokich jeziorach krasowych na Pojezierzu Łęczyńsko-Włodawskim. Ann. Univ. M. Curie-Skłodowska, Sec. C 35: 43-52. (in Polish with English summary)

KARCZMARZ K., KRAUSE W. 1979. A new locality of Lychnothamnus barbatus (Meyen) Leonh. in Poland. Acta Hydrobiologica 21: 213-217.

KARCZMARZ K., MALICKI J. 1965. Rozmieszczenie mniej znanych gatunków ramienic na Lubelszczyźnie. Ann. Univ. M. Curie-Skłodowska, Sec. B 20 (12): 281-291. (in Polish with English summary)

KARCZMARZ K., MALICKI J. 1971. Zespoły i ekologia ramienic Pojezierza Łęczyńsko-Włodawskiego. Ann. Univ. M. Curie-Skłodowska, Sec. C 26 (23): 297-327. (in Polish with English summary)

KAROL K.G., McCOURT R.M., CIMINO M.T., DELWICHE C.F. 2001. The closest living relatives of plants. Science 294: 2351-2353.

KRAUSE W. 1997. Charales (Charophceae). Süsswasserflora von Mitteleuropa. 18, pp. 1-202. Gustav Fisher Verlag.

MEIERS S.T., ROOTES W.L, PROCTOR V.W., CHAPMAN R.L. 1997. Phylogeny of the Characeae (Charophyta) inferred from Organismal and Molecular characters. Arch. Protistenkd. 148: 308-317.
PEŁECHATY M., PEŁECHATA A., PUKACZ A. 2007. Flora i roślinność ramienicowa na tle stanu trofii jezior Pojezierza Lubuskiego (środkowo-zachodnia Polska). pp. 1-137. Bogucki Wydawnictwo Naukowe. (in Polish with English summary)

RADWAN S. 1996. Funkcjonowanie systemów wodno błotnych w obszarach chronionych Polesia. pp. 1-152. Wyd. UMCS. (in Polish)

SIEMIŃSKA J., BĄK M., DZIEDZIC J., GĄBKA M., GRYGOROWICZ P., MROZIŃSKA T., PEŁECHATY M., OWSIANNY P.M., PLIŃSKI M., WITKOWSKI A. 2006. Red list of the algae in Poland. In: Z. Mirek, K. Zarzycki, W. Wojewoda, Z. Szeląg (eds), Red list of plants and fungi in Poland. W. Szafer Institute of Botany, Polish Academy of Science, Kraków, pp. 37-52.

SPENCE D.H.N. 1982. The zonation of plants in freshwater lakes. Adv. Ecol. Res. 12: 37-152.

SUGIER P. 2001. The dynamics of aquatic and rush vegetation and landscape changes of the lake Moszne in the Polesie National Park. Ekológia (Bratislava) 20 (4): 257-264.

SUGIER P. 2008. Characteristics of Lake Rogoźno macrophytes and their role in preservation of biodiversity. Teka Kom. Ochr. Kszt. Środ. Przyr. PAN, 5A: 138-144.

SUGIER P., PEŁECHATY M., GABBKA M., OWSIANNY P.M., PUKACZ A., CIECIERSKA H., KOLADA A. 2009. Lychnothamnus barbatus: global history and distribution in Poland. Charophytes 2 (1): 19-24.

ŚWIĘS F. 1966. Chara crassicaulis Schleicher - nowy gatunek dla flory południowej Polski. Fragm. Flor. et Geobot. 12: 215-216. (in Polish with English summary)

URBANIAK J. 2005. Z dotychczasowych badań nad fykoflora ramienic (Charophyta) na Dolnym Śląsku. Anales Silesiae 34: 21-25. (in Polish with English summary)

URBANIAK J. 2007. Distribution of Chara braunii Gmellin 1826 (Charophyta) in Poland. Acta Soc. Bot. Pol. 76 (4): 313 -320 .

URBANIAK J., GĄBKA M., BLAžENČIC J. 2008. Nitella tenuissima, a rare Charophyte in Central and Southern Europe. Cryptogamie, Algologie 29 (2): 161-171.

URBANIAK J., KRAWCZYK R. 2008. Nowe stanowisko Nitella gracilis (Characeae) w Kotlinie Sandomierskiej. Fragm. Flor. Geobot. Polonica 15 (1): 142-145. (in Polish with English summary)

URBANIAK J. 2009. Oospore variation in Nitella gracilis and Nitella mucronata (Charales, Charophyceae) from Poland. Biologia 64 (2): 252-260.

URBANIAK J. 2010. Analysis of morphological characters of Chara baltica, C. hispida, C. horrida, and C. rudis from Europe. Plant Syst. Evol. 286:209-221. DOI 10.1007/s00606010-0301-6.

URBANIAK J. 2010a. Ramienice (Charophyta) Polski północnowschodniej - cz. I. Fragm. Flor. Geobot. Polonica 17(2): 158-164. (in Polish)

URBANIAK J., KRAWCZYK R., KARCZMARZ K. 2010. Ramienice (Charophyta) wybranych regionów Polski - Kotlina Sandomierska, Karpaty. Fragm. Flor. Geobot. Polonica 17(1): 165-169. (in Polish)

ZAJĄC A. 1978. Atlas of distribution of vascular plants in Poland (ATPOL). Taxon 27: 481-484. 